\title{
Processing Efficiency, Simulation and Enzyme Activities Analysis of an Air-Lift Multilevel Circulation Membrane Bioreactor (AMCMBR) on Marine Domestic Sewage Treatment
}

\author{
Yuhang Cai ${ }^{1}$, Xin Li ${ }^{2}$, Asad A. Zaidi', Yue Shi ${ }^{1 *}$, Kun Zhang ${ }^{1}$, Peiqi Sun ${ }^{1}$, Zheng Lu \\ ${ }^{1}$ College of Power and Energy Engineering, Harbin Engineering University, Harbin 150001, Heilongjiang Province, China \\ 2 China Aviation Development Institute, No. 1 Wanlian Road, Shenhe District, Shenyang City, China \\ * Corresponding author, e-mail: shiyue@hrbeu.edu.cn
}

Received: 01 November 2018, Accepted: 08 January 2019, Published online: 25 March 2019

\begin{abstract}
The implementation of latest International Maritime Organization emission standard raised stringent requirements for marine domestic sewage discharge. In this study, an air-lift multilevel circulation membrane reactor (AMCMBR) was operated to analyze effects of various ecological factors on effluent of marine domestic sewage. Back-propagation (BP)-Artificial Neural Network (ANN) was used to simulate effect of each ecological factor on reactor performance. The activities of four enzymes were investigated to reveal microbial activities in reactor. Experimental results indicates that the Hydraulic Retention Time (HRT), Mixed Liquid Suspended Solids (MLSS) and pH value cannot be less than $4 \mathrm{~h}, 3000 \mathrm{mg} / \mathrm{L}$ and 6, respectively to meet the IMO emission standard for effluent COD. A small value of mean square error (0.00147) indicated that BP-ANN can well describe the relationship between operation parameters (influent COD, HRT, MLSS, and $\mathrm{pH}$ ) and effluent COD. The order of relative importance was $\mathrm{pH} \approx \mathrm{MLSS}>\mathrm{HRT}>$ influent COD. Polyphenol oxidase and urease can serve as indicating factors for reactor performance, whereas dehydrogenase and nitrate reductase showed less susceptible towards varied influent COD and MLSS.
\end{abstract}

Keywords

air-lift multilevel circulation membrane reactor (AMCMBR), Back-propagation -Artificial Neural Network (BPANN ecological factor), enzyme activity

\section{Introduction}

With the rapid economic development and increasing prosperity of the shipping industry, deteriorated marine environment have attracted more and more attention all around the world. Under this situation, International Maritime Organization (IMO) generated tougher emission standards for marine sewage discharge to protect marine environment [1]. Based on the implementation of the latest IMO standard in 2010, ship sewage discharge standard was significantly improved. Among various reactor types, membrane reactor (MBR) showed obvious advantages of perfect treatment effects and smaller treatment volume. Nowadays, this technology has become well-known for ship sewage treatment $[2,3]$. However, most of the researches focus on various aspects of onshore MBRs. The offshore MBRs, which has been considered as an effective option for marine sewage treatment should be supported to adapt the rapid development of shipping industry.
Amongst many factors that affect the removal efficiency of MBR on marine domestic sewage HRT, influent COD, MLSS and $\mathrm{pH}$ were considered as important factors and investigated by some researches [4-8]. Wang et al. [5] quantifies the influence of seven operating parameters on the efficiency of domestic wastewater treatment. The results show that MLSS and temperature accounted for the largest proportion. Chang et al. [4] and Fallah et al. [7] reported that HRT is the most important factor in MBR performance. The activated sludge determined the treatment efficiency and effects of sewage treatment in MBR reactor performance $[9,10]$, and the corresponding studies mainly focus on sludge bulking, sludge reduction etc. [11-14]. The analysis of bacterial activity based on bacterial respiratory movement of MBR reactor was also published [15]. However, the research on microbial activity in active material and sewage gained less attention. 
In this study, a novel air-lift multilevel circulation membrane bioreactor (AMCMBR) was used to treat marine domestic sewage. Each ecological factor that influenced treatment effect was studied and Back-propagation (BP)Artificial Neural Network (ANN) was used to analyze the impact of each ecological factor on reactor performance. Besides, microbial enzyme activities of activated sludge were studied, which was based on changing sludge concentration and influent COD. As a result, microbial characteristics in the reactor can be observed and then become the guidance of operation and treatment effect for the reactor.

\section{Materials and Methods}

\subsection{Raw Material}

The inoculated sludge used in the reactor was obtained from the aeration tank of Harbin Wenchang sewage treatment plant, Harbin, Heilongjiang province, China. It was domesticated by using molasses for about 10 days. The sewage used in this experiment was artificially diluted by molasses. The feed composition of initial synthetic wastewater for experimental setup was set by mixing the local marine sewage with synthetic wastewater in certain proportions (i.e. $50 \%$ black wastewater $+50 \%$ synthetic wastewater. The composition of the synthetic wastewater was as follows: COD - $900 \mathrm{mg} / \mathrm{L}$, starch - $742.5 \mathrm{mg} / \mathrm{L}$, molasses $1.65 \mathrm{ml} / \mathrm{L},\left(\mathrm{NH}_{4}\right)_{2} \mathrm{SO}_{4}-528.75 \mathrm{mg} / \mathrm{L}, \mathrm{KH}_{2} \mathrm{PO}_{4}-121.5 \mathrm{mg} / \mathrm{L}$, $\mathrm{MgSO}_{4} \cdot 7 \mathrm{H}_{2} \mathrm{O}-173.25 \mathrm{mg} / \mathrm{L}, \mathrm{CH}_{3} \mathrm{COONa}-81 \mathrm{mg} / \mathrm{L}$, $\mathrm{CaCl}_{2} \cdot 2 \mathrm{H}_{2} \mathrm{O}-15.75 \mathrm{mg} / \mathrm{L}, \mathrm{MnSO}_{4} \cdot \mathrm{H}_{2} \mathrm{O}-15.75 \mathrm{mg} / \mathrm{L}$, peptone $-36.564 \mathrm{mg} / \mathrm{L}$, and $\mathrm{FeSO}_{4} \cdot 7 \mathrm{H}_{2} \mathrm{O}-3.376 \mathrm{mg} / \mathrm{L}$.

\subsection{AMCMBR set-up}

The main reactor of the AMCMBR adopted a built-in membrane design, which reduced the reactor volume and promoted reactor sludge load. A built-in membrane design means the membrane is immersed in an aerobic tank. The basic parameters were as follows: The total volume, height, diameter and effective volume were $21 \mathrm{~L}, 21 \mathrm{~cm}$, $15 \mathrm{~cm}$ and $16 \mathrm{~L}$ respectively. There was a baffle with an open pore inside the reactor. The novel bare vertical beam column air-blowing hollow fiber membrane module (Shanghai Dehong Biomedical Science and Technology Development Co., LTD) was used in this reactor with the effective length of $600 \mathrm{~mm}$, the $\mathrm{pH}$ range of $2 \sim 10$, the membrane area of $1.5 \mathrm{~m}^{2}$, and the membrane aperture of $0.01 \mu \mathrm{m}$. Center-fixed installation of sand head aeration was used as the aerator to form a large amount of local ventilation. Meanwhile, it would form multilevel circulations through the open pore of baffle to mix gas and water adequately and made the amount of dissolved oxygen above $2 \mathrm{mg} / \mathrm{L}$. In addition, the surface of the membrane forms a cross-flow arrangement, which has a certain flushing effect on the membrane module and prolongs the running time of the membrane module. The reactor operation was set as 9 min for positive pumping and $30 \mathrm{sec}$ for back flushing to guarantee the normal membrane flux.

During the experiment, reactor aeration rate was $600 \mathrm{~L} / \mathrm{h}$ according to the daily sewage treatment volume and pollutants loading. The construction of reactor is shown in Fig. 1. The process of reactor was as follows: The wastewater from inlet tank flowed into the reactor through charging pump. At the same time, oxygen was pumped into the AMCMBR through aeration head at the bottom of AMCMBR by aeration pump. The gas-liquid mixture flowed directly into the reaction tank. The two baffles were constructed in the reaction tank, which form multilevel circulations. Finally, the treated wastewater flow from the membrane module, completing the process.

\subsection{AMCMBR start-up and operation}

The sludge was added to the AMCMBRs and filled with synthetic wastewater. First, the sludge was subjected to static settlement for $24 \mathrm{~h}$. The supernatant was removed and the solid sludge added to the AMCMBRs filled with synthetic wastewater. The following culture conditions were set up: dissolved oxygen (DO) 2.0-3.0 $\mathrm{mg} \mathrm{L}^{-1}$, influent COD $400 \mathrm{mg} \mathrm{L}{ }^{-1}$, HRT 8h, MLSS $4000 \mathrm{mg} / \mathrm{L}$, $\mathrm{pH} 7.5$, essential nutrition were added to the AMCMBRs by exchanging the treated water with the untreated synthetic wastewater. When the sludge flocculation formed in the reactor and effluent COD was less than $100 \mathrm{mg} \mathrm{L}^{-1}$,

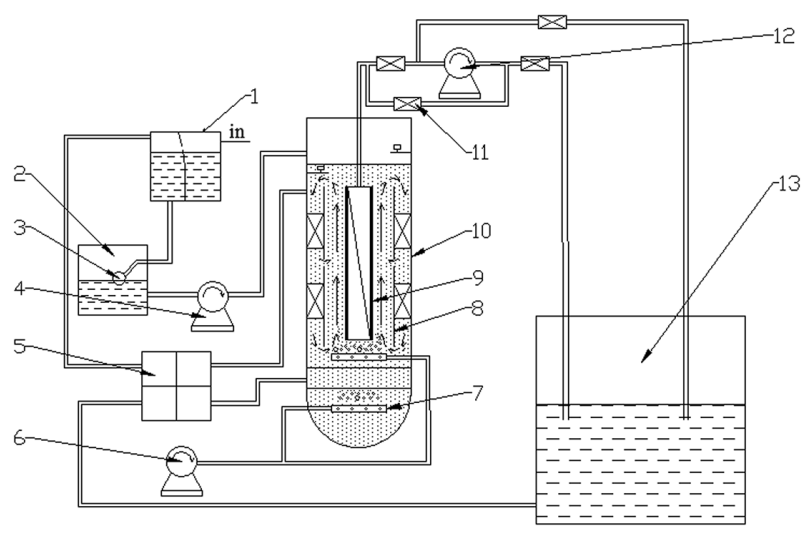

Fig. 1 The construction of the AMCMBR (1. pretreatment tank; 2. inlet tank; 3. float valve; 4. charging pump; 5. dosing box; 6. aeration pump;

7. aeration head; 8 . baffle; 9 . membrane module; 10 . reaction tank; 11. electromagnetic valve; 12 . vacuum pump; 13. outlet tank) 
the start-up of the experiment began. All experiments were conducted under room temperature. Details of operating conditions of the four stages are summarized in Table 1. The main monitoring index was as follows: COD concentration of influent and effluent and the activities of constitutive enzymes.

\subsection{Analytical Methods}

The analytical methods employed of this experiment were as follows: COD and MLSS were measured by standard method [16], $\mathrm{pH}$ values were measured by a $\mathrm{pH}$ meter (PHS-3C, Shanghai Leici). The measuring methods of each of enzyme activity were as follows: Polyphenol oxidase was measured by pyrogallol colorimetric method [17], Urease was measured by colorimetric method [18], Dehydrogenase was measured by TTC method [19], Nitrate reductase was measured by spectrophotometer method [20].

\subsection{Simulation of the Reactor Performance}

BP-ANN was established by using the software program MATLAB and used to describe the effect of each ecological factor (influent COD, $\mathrm{pH}$, HRT and MLSS) on MBR reactor treatment. By using BP-ANN, the experimental results of multilevel circulation membrane biological reactor can be simulated and the influence of each ecological factor on treatment effect can be quantitatively analyzed. Models were based on the BP-ANN theory and linear regression techniques. The topological architecture of BP-ANN models were illustrated in Fig. 2, which shows a three-level networks. Each network comprises four nodes in input layers, undetermined nodes in hidden layers and one node in the output. Each node is a BP neuron. Influent COD, HRT, MLSS and $\mathrm{pH}$ of the AMCMBR are the initial variables of input for each network. Effluent COD concentration, are the variables.

Functions (used the MATLAB toolbox) and parameters used in the model are described as follows: training function, "traingdx" arithmetic; stimulative functions, "logsig" (input layer), "tansig" (hidden layer) and "purelin" (output layer); momentumcomponent (mc), 0.9; study rate (lr), 0.8; increased coefficient of study rate (lr_inc), 1.05; decreased coefficient of study rate ( $\left.1 \mathrm{r} \_\mathrm{dec}\right), 0.7$; hidden neurons (net), 10; The preset maximum training iterations and error accuracy are $\mathrm{K}=1000$ and $\xi=10-2$; and joint weight, stochasticin $[-1,1]$. The function of BP neural network was to separate the weight between hidden layer \& output layer and make it associate with input layer. The weights of neural units in the network not only can store information but
Table 1 Operating conditions of the four stages

\begin{tabular}{lccccc}
\hline $\begin{array}{l}\text { Steady } \\
\text { state }\end{array}$ & $\begin{array}{c}\text { Influent COD } \\
\mathrm{mg} / \mathrm{L}\end{array}$ & $\begin{array}{c}\text { HRT } \\
\mathrm{h}\end{array}$ & $\begin{array}{c}\text { MLSS } \\
\mathrm{mg} / \mathrm{L}\end{array}$ & $\mathrm{pH}$ & $\begin{array}{c}\text { Duration } \\
\text { days }\end{array}$ \\
\hline $\mathrm{I}$ & $400-1700$ & 8 & 400 & 7.5 & 17 \\
II & 1200 & $4-8$ & 4000 & 7.5 & 18 \\
III & 1200 & 8 & $2000-10000$ & 7.5 & 18 \\
IV & 1200 & 8 & 4000 & $5.7-9.8$ & 18 \\
\hline
\end{tabular}

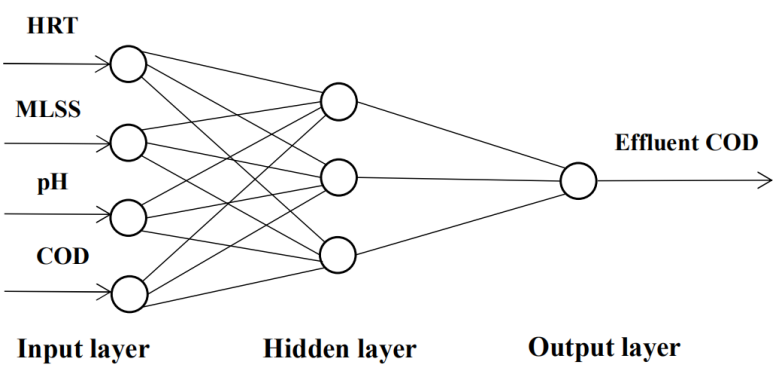

Fig. 2 The topological architecture of BPNN

also can guide the direction of the information. According to information flow theory, the value of weights determines the direction which information flow towards. As a result, the value of weights shows the contributions of the input factors to the final output [21]. Its algorithm was shown in the Eq. (1) and Eq. (2).

$$
\begin{aligned}
& Q_{i h}=\frac{\left|W_{i h}\right|}{\left|\sum_{i=1}^{n i} W_{i h}\right|} \\
& R I(\%)_{i}=\frac{\sum_{h=1}^{n h} Q_{i h}}{\sum_{h=1}^{n h} \sum_{i=1}^{n i} Q_{i h}} \times 100
\end{aligned}
$$

Where $W_{i h}$ is weight between input layer and hidden layer and $\mathrm{nh}$ and ni are numbers of neural units in input layer and hidden layer, respectively.

\section{Results and discussion}

\subsection{Influence of different ecological factors on marine sewage treatment}

\subsubsection{Influent COD}

The influence of influent COD change on effluent COD is shown in Fig. 3 (a). When influent COD was about $400,800,1200,1600 \mathrm{mg} / \mathrm{L}$, there exists little fluctuation in effluent COD with the values ranged from 60 to $120 \mathrm{mg} / \mathrm{L}$. Effluent COD produce slight increase along with the increase of influent COD, and then became stable, indicating that microorganisms in the reactor can be 

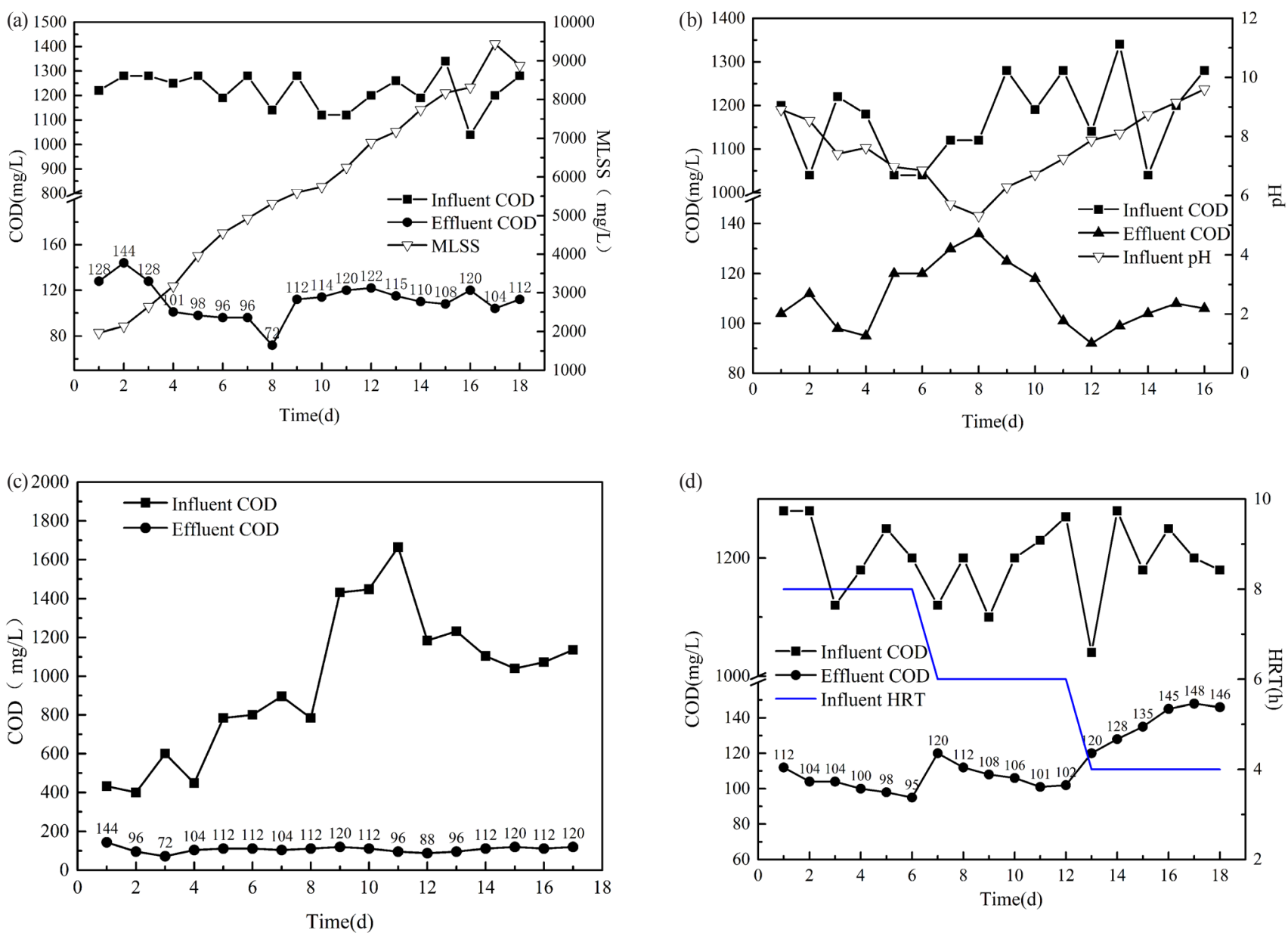

Fig. 3 (a) Influence of influent COD change on effluent COD (b) The Effect of HRT change on sewage treatment of reactor (c) Influence of MLSS change on reactor sewage treatment (d) Effluent COD change with pH and influent COD

effective under increasing organic load. Besides, effluent COD back to lower level and kept it. This indicates combined removal mechanism for the removal of organic pollutants by the MBR system, that is, microbial degradation and membrane filtration [22-26]. The MBR reactor present a certain degree of impact resistance and stable operation towards increasing influent COD, and all of effluent COD values can meet the IMO emission standard.

\subsubsection{HRT}

HRT is an important controllable parameter in sewage treatment processes which is directly related to the organic load. The influence of HRT change on sewage treatment of reactor is shown in Fig. 3 (b). The influent COD concentration was maintained at about $1200 \mathrm{mg} / \mathrm{L}$. It was noted that the average permeate COD was less than $125 \mathrm{mg} / \mathrm{L}$ (IMO standard) when HRTs were 8 and $6 \mathrm{~h}$. However,when the HRT was reduced to $4 \mathrm{~h}$, the average permeate COD increased to $130 \mathrm{mg} / \mathrm{L}$ resulting in the performance of AMCMBR was destroyed. The phenomenon indicated that as the HRT shortened, the time of sewage staying in the reactor was correspondingly shortened and the decomposition time of microorganism was reduced. The reason for this phenomenon lies in the fact that there may occur inhibition in microbial community during low HRT stage [27]. Therefore, it could be concluded that an HRT of more than $6 \mathrm{~h}$ was considered tobe optimum for this system to treat ship sewage.

\subsubsection{MLSS}

Influence of MLSS change on reactor sewage treatment is shown in Fig. 3 (c). The MLSS increased gradually from 2000 to $10000 \mathrm{mg} / \mathrm{L}$, with effluent COD concentration increased to $120 \mathrm{mg} / \mathrm{L}$ and kept stable before decreasing to minimum concentration $(72 \mathrm{mg} / \mathrm{L})$. During the first three days of the experiment, the effluent COD kept a high level $(\geq 120 \mathrm{mg} / \mathrm{L})$. This is mainly because the small amount of activated sludge is resulting in too 
few microorganisms. Activated sludge is the core material to MBR reactor, and its amount had direct impact on the effectiveness of wastewater treatment [28]. It should be noticed that the influent COD was lower when MLSS was $4000 \mathrm{mg} / \mathrm{L}$. However, as the concentration of activated sludge increased above $5000 \mathrm{mg} / \mathrm{L}$, the effluent COD followed a increasing trend. High sludge concentration can increases the rate of oxygen consumption, resulting in an insufficient DO and axoic environment. This phenomenon can reduce COD removal efficiency. Therefore, in order to guarantee a perfect effluent quality to meet the IMO emission standard, sludge concentration inside the reactor should be kept 3000-5000 mg/L.

\subsection{4 pH}

Sewage $\mathrm{pH}$ is closely related to the microbial activity of activated sludge. It was believed that the changes in $\mathrm{pH}$ value can change charge properties of microbial cytoplasmic membrane and then affect microorganisms of activated sludge on the decomposition of pollutants, as well as affect the composition of enzyme protein and the dissociation state of substrate state. Thereby the combination of enzyme and substrate was affected, and the microorganisms face obstacles in respiration and metabolism which further affect the sewage treatment. The effect of effluent COD change with $\mathrm{pH}$ and influent COD change is shown in Fig. 3 (d). With the constant influent COD and decrease of $\mathrm{pH}$ value, effluent COD kept stable. This exemplified that microorganism possessed ability of self-adjustment. However, it is noticeable that when the $\mathrm{pH}$ dropped to 5.7, the effluent COD concentrations increased $(136 \mathrm{mg} / \mathrm{L})$. This result suggested that acidic conditions have a huge impact on AMCMBR. This is mainly because acidic conditions have obvious inhibitory effects on nitrite-reductase, which greatly reduces the system's nitrification and denitrification capacity. This reason was in consistency with Yue et al. [29] and Cao et al. [30]. Therefore, in order to achieve a perfect treatment effect and to ensure that effluent COD strictly meet the IMO emission standard, $\mathrm{pH}$ value should be kept at neutral and not lower than 6 .

\subsection{Enzyme activities under different influent COD and MLSS}

Through the analysis of the effect of ecological factors on MBR reactor, activated sludge found to be the most influential factor for sewage treatment. The microorganisms in activated sludge played key role in pollutant decomposition. The microbial decomposition rate on organic matter was directly related to the enzyme activity of microorganisms. COD removal was primarily via biological removal because of the better enzymatic activities and more microbial species in the MBR system [31-33]. Thus, the microbial enzyme activities were analyzed to reveal the effect and rate on sewage treatment. The sludge sample was taken in the fourth, eighth, eleventh, and thirteenth day to analyze enzyme activities. Within these four days, influent COD changed among 600 1200 mg/L, and sludge concentration was about $3000 \sim 5000 \mathrm{mg} / \mathrm{L}$.

\subsubsection{Polyphenol Oxidase}

Polyphenol oxidase is a widely distributive enzyme, which catalyzed the phenolic compounds to form quinone. This kind of quinone generates a series of dehydration \& polymerization, and formed black substances [34-36]. Polyphenol oxidase in MBR reactor is primarily used to evaluate the phenolic compounds of domestic sewage. Accordingly, the treatment rate of phenolic compounds in domestic sewage was determined by the polyphenol oxidase activity. As shown in Fig. 4 (a), polyphenol oxidase increased with the increase of MLSS and influent COD from the original value of $66 \mu \cdot \mathrm{mol} / \mathrm{h} \cdot \mathrm{gfw}$ to $99 \mu \cdot \mathrm{mol} / \mathrm{h} \cdot \mathrm{gfw}$. It also decreased with the decrease of MLSS and influent COD. This illustrated that polyphenol oxidase was positively related to MLSS and influent COD. Previous research reported that as the COD increases, the amount of substances decomposed and utilized increases, which promotes the activity of the Polyphenol oxidase, and the total amount of microorganisms increases with increasing of MLSS [37]. Polyphenol oxidase activity increased with the increase of influent COD and sludge concentration inside the reactor, suggesting that microorganism enhanced its processing and decomposition capacity of phenols in the sludge. Therefore, Polyphenol oxidase can serve as the indicating factors for reactor performance.

\subsubsection{Urease}

Urease is a kind of metal enzyme and a highly effective decomposition catalyst of urea which can catalyze urea hydrolysis to generate ammonia and carbon dioxide, as well as the hydrolysis of C-N bond of amide [38, 39]. Peptide bonds in matrix molecules are hydrolyzed by enzymatic reactions, and their size is closely related to the number of matrix microorganisms, organic matter content and TN content [40]. In activated sludge, urease can catalyze the decomposition of urea and C-N bond-containing compound of sludge and convert them to harmless 

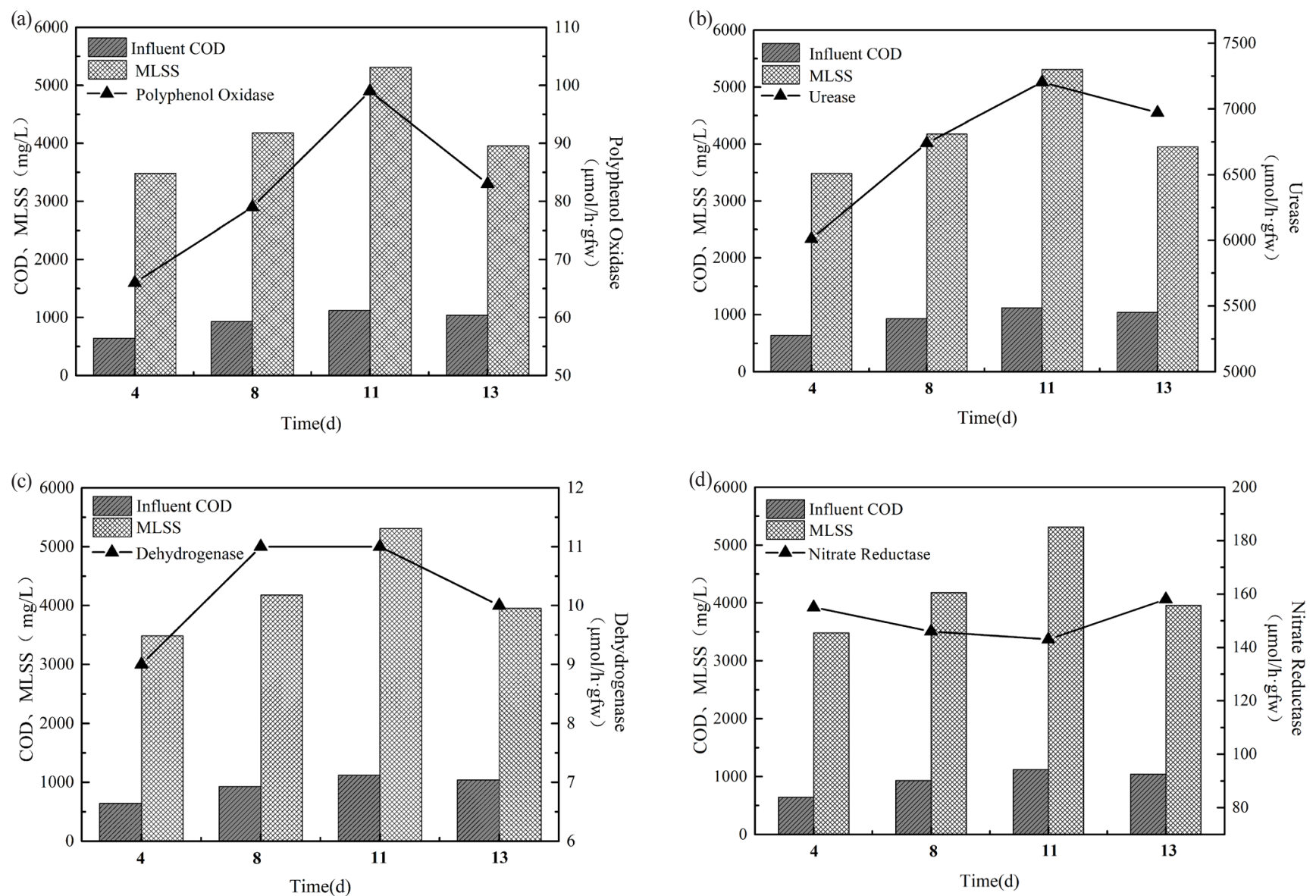

Fig. 4 (a) Polyphenol Oxidase activities under different Influent COD and MLSS (b) Urease activities under different Influent COD and MLSS (c) Dehydrogenase activities under different Influent COD and MLSS (d) Nitrate reductase activities under different Influent COD and MLSS

inorganic matter. The decomposition of urea and other components of sewage are directly restricted by urease activity. Thus, the high activity of urease indicated that the environment is more conducive to the growth and reproduction of microorganisms, and the better the purification effect of pollutants [41]. As shown in Fig. 4 (b), urease activity increased with the increase of influent COD and MLSS, thereby it illustrated that microbial decomposition of urease also increased with the increase of influent COD and MLSS. This indicates that urease is a key factor in the operation of AMCMBR.

\subsubsection{Dehydrogenase}

In the oxidation process of organic matter, dehydrogenase is the first enzyme acting on the metabolic substrate. The measurement of dehydrogenase activity is used for the evaluation of sewage biochemical treatment efficiency and water quality toxicity testing. In the process of sewage treatment, dehydrogenase can catalyze the dehydrogenation of organic matter. During this process, the hydrogen atom was delivered to hydrogen receptor to finish redox reaction. The degree of dehydrogenase activity reflected microbial activity and ability of degrading pollutants in activated sludge. As shown in Fig. 4 (c), dehydrogenase activity increased with the increase of influent COD and MLSS. This mainly because the activity of activated hydrogen atom of microorganism increased with the increase of influent COD and MLSS. Consequently, microbial capability of degrading and efficiency of biochemical sewage treatment were enhanced. Previous researches reported that the activity of dehydrogenase can directly indicate the ability of cells to degrade their matrix, and also represents the activity of activated sludge, which has certain correlation with COD and BOD [42]. So it seems can be a factor to monitor the performance of reactor. However, dehydrogenase activity changed with the variation of COD and MLSS, it is not very remarkable with the values around $10 \mu \cdot \mathrm{mol} / \mathrm{h} \cdot \mathrm{gfw}$. The reason for this difference may be caused by the unique design of the AMCMBR, which only have an aerobic zone. 
Fang et al. [43] explored the variation of four enzymes in the process of simulating urban domestic sewage by $\mathrm{A} / \mathrm{O}$ process; the results indicated that the dehydrogenase activity in the anaerobic zone is greater than that in the aerobic zone. This mainly because the dehydrogenase is the major enzyme of anaerobic microorganisms in anaerobic zone. But the internal mechanism still needs further research. Thus, the detection of dehydrogenase activity was not ideal to be the monitoring factor of AMCMBR treatment efficiency and biodegradation of pollutants.

\subsubsection{Nitrate reductase}

Nitrate reductase is an important enzyme in the assimilation process of the exogenous nitrate. The nitrate reductase of aerobic denitrifying bacteria can be divided into two kinds, including periplasmic nitrate reductase and membrane-bound nitrate reductase. Generally, periplasmic nitrate reductase of aerobic denitrification is prior to present its activity, and its activity is substantially independent of the inhibition of oxygen molecules [44]. The level of periplasmic nitrate reductase activity is affected by the amount of carbon source in environment. In aerobic environment, most of nitrate reductase is periplasmic nitrate reductase. As shown in Fig. 4 (d), effluent COD and MLSS are negative relevant to periplasmic nitrate reductase activity, illustrating that aerobic denitrification was inhibited. The carbon resource in reactor increased with the increase of influent COD, which promoted metabolism of carbon atom, thus the metabolism of nitrogen source was inhibited. It should be noticed that nitrate reductase is reduced with the increase of influent COD and MLSS with the values between $140 \mu \cdot \mathrm{mol} / \mathrm{h} \cdot \mathrm{gfw}$ to $160 \mu \cdot \mathrm{mol} / \mathrm{h} \cdot \mathrm{gfw}$ (Fig. 4 (d), which is hard to indicate the strength of wastewater treatment by activated sludge microorganisms. This may be due to the integrated aerobic membrane bioreactor structure of the reactor. Because of the higher concentration of DO, the activity of nitrate reductase is inhabited. This is mainly because denitrification preferentially performs aerobic respiration when molecular oxygen and nitrate are present together [45], while denitrification is mainly an anaerobic reaction, and the enzyme activity is higher under hypoxic conditions. When the oxygen concentration is too high, the formation of anaerobic respiration enzyme is inhibited and the nitrate reductase activity is inhibited. Chen et al. [23] and other studies have shown that the lower concentration of dissolved oxygen is most suitable for simultaneous nitrification and aerobic denitrification (SND). In conclusion, the detection of nitrate reductase activity was not ideal as the monitoring factor of AMCMBR reactor on treatment efficiency and biodegradtion of pollutants.

\subsection{Simulation of the reactor performance by BP Neural Network}

\subsubsection{Mathematical statistical model for effluent COD}

BP Neural Network was established to describe the effect of each environmental factor (influent COD, HRT, MLSS and $\mathrm{pH}$ ) on AMCMBR reactor treatment. The model program for COD selected the data previously found (see Section 3.1) of the AMCMBR system as model training value. The results of regression analysis showed that the correlation coefficient between prediction value and experimental value was 0.99 , which indicated that simulation results were in good agreement with the experimental data. The comparison of predicted and experimental values under different conditions is listed in Table 2. It can be observed that the maximum error was $9.10 \%$ while the smallest error was $0.87 \%$. Shi et al. [21] established a BPANN model based on the prototype experiment for treating herb wastewater by up-flow Anaerobic Sludge Bed and Anaerobic Filter reactor (UASBAF). The errors of $1.89-19.23 \%$ were present in the experiment. Chen et al. $[46,47]$ used BPANN model to simulate the performance of the two-phase anaerobic digestion (TPAD) and up-flow anaerobic sludge blanket (UASB) system, which achieved a feasible predicted result. The model well fitted the experimental data in terms of reactors effluent COD, having a small value of mean square error $(0.00147)$. This showed that the simulation model built on the BPANN theory is an ideal mean to simulate and predict the organic substance removal by the AMCMBR system.

\subsubsection{Principal factor identification}

BP-neural network was used to analyze the relationships of each ecological factor on treatment efficiency. After 5000 times training, the mean square error (MSE) was 0.00998 and then training was ended. The weights among layers and the bias of each neuron were correspondingly determined, and they are shown in Table 3 and Table 4.

The influence of each ecological factor on treatment effect is shown in Fig. 5. Each of the ecological factors was put into BP neural network and analyzed. It is figured out that the importance of the factors was: $\mathrm{pH} \approx$ MLSS $>$ HRT $>$ influent COD. These results are consistent with previous study [21], which reported that used the relative importance (RI) to grasp the essential relations among 
Table 2 Comparative Analysis of Experimental Value and BP-ANN Value.

\begin{tabular}{|c|c|c|c|c|c|c|c|}
\hline $\mathrm{S}$ & $\mathrm{pH}$ & $\begin{array}{c}\text { HRT } \\
\mathrm{h}\end{array}$ & $\begin{array}{l}\text { MLSS } \\
\mathrm{mg} / \mathrm{L}\end{array}$ & $\begin{array}{c}\text { Influent COD } \\
\mathrm{mg} / \mathrm{L}\end{array}$ & $\begin{array}{c}\text { Exp. value } \\
(\mathrm{mg} / \mathrm{L})\end{array}$ & $\begin{array}{c}\text { BP-ANN value } \\
\mathrm{mg} / \mathrm{L}\end{array}$ & $\begin{array}{c}\text { Error } \\
(\%)\end{array}$ \\
\hline 1 & 7.41 & 8 & 4413 & 455 & 85 & 88 & 3.53 \\
\hline 2 & 7.62 & 8 & 4748 & 800 & 110 & 100 & 9.10 \\
\hline 3 & 7.25 & 8 & 4546 & 1056 & 105 & 110 & 4.76 \\
\hline 4 & 7.87 & 8 & 4237 & 1216 & 96 & 101 & 5.2 \\
\hline 5 & 6.97 & 8 & 4427 & 1454 & 115 & 114 & 0.87 \\
\hline 6 & 7.16 & 8 & 4419 & 1598 & 99 & 98 & 1.01 \\
\hline 7 & 7.71 & 8 & 4128 & 1280 & 104 & 100 & 3.85 \\
\hline 8 & 7.32 & 6 & 4227 & 1218 & 112 & 105 & 6.25 \\
\hline 9 & 7.29 & 4 & 4081 & 1257 & 145 & 135 & 6.90 \\
\hline 10 & 6.92 & 8 & 2091 & 1221 & 128 & 120 & 6.25 \\
\hline 11 & 6.91 & 8 & 4548 & 1199 & 96 & 100 & 4.17 \\
\hline 12 & 7.54 & 8 & 6245 & 1125 & 120 & 117 & 2.50 \\
\hline 13 & 7.41 & 8 & 8167 & 1346 & 108 & 110 & 1.85 \\
\hline 14 & 5.32 & 8 & 4410 & 1121 & 136 & 129 & 5.15 \\
\hline 15 & 6.72 & 8 & 3989 & 1190 & 118 & 115 & 2.54 \\
\hline 16 & 7.62 & 8 & 4057 & 1187 & 95 & 96 & 1.05 \\
\hline 17 & 8.54 & 8 & 4238 & 1042 & 112 & 110 & 1.79 \\
\hline 18 & 9.6 & 8 & 4426 & 1283 & 106 & 105 & 0.94 \\
\hline Avg & & & & & & & 3.67 \\
\hline
\end{tabular}

Table 3 Weights between Input Layer and Hidden Layer

\begin{tabular}{lcccc}
\hline \multirow{2}{*}{ Hidden layer } & \multicolumn{4}{c}{ Input layer } \\
\cline { 2 - 5 } & 1 & 2 & 3 & 4 \\
\hline 1 & 0.3933 & -2.1874 & -0.9811 & -4.4914 \\
2 & -1.9875 & -2.7443 & 0.1365 & 1.1926 \\
3 & -0.1012 & -1.6209 & 3.7450 & 0.8608 \\
\hline
\end{tabular}

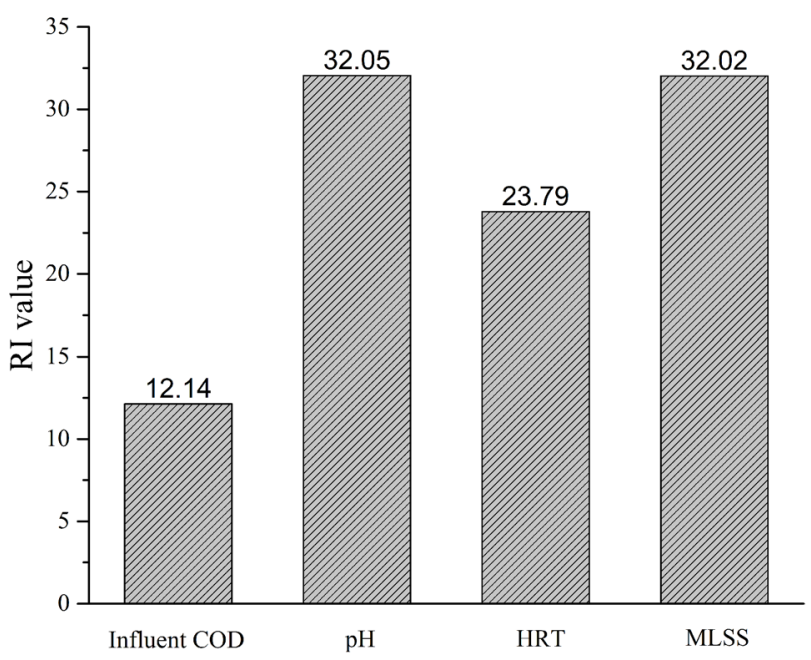

Fig. 5 Influence of each ecological factors on treatment effect. RI value represents the importance of the operational parameters for the reactor, the higher the RI value, the greater influence of this parameter in the AMCMBR.
Table 4 Weights between Output Layer and Hidden Layer

\begin{tabular}{lccc}
\hline & \multicolumn{3}{c}{ Hidden layer } \\
\hline Output layer & 1 & 2 & 3 \\
Weight & -4.5748 & 1.7533 & -1.2155 \\
\hline
\end{tabular}

all impact factors in UASBAF system. Consequently, the most influential effects of ecological factors on MBR treatment were $\mathrm{pH}$ and MLSS. Reactor was more sensitive to HRT than influent COD. It is better to increase HRT than to reduce influent COD, when the reactor's pollutants removal efficiency decreases.

\section{Conclusions}

Based on the experimental results, the conclusions are listed as follows:

1. When influent COD ranged among 400-1600 mg/L, the reactor ran steadily, and effluent COD can meet IMO emission standard. Meanwhile, sludge concentration of ecological factors, HRT and $\mathrm{pH}$ value should be maintained at $3000-5000 \mathrm{mg} / \mathrm{L}, 6 \mathrm{~h}$ and above 6 respectively to make sure a preferable reactor performance. 
2. A small value of mean square error (0.00147) indicated that BP-ANN can well describe the relationship between parameters (influent COD, HRT, MLSS, and $\mathrm{pH}$ ) and effluent COD. The order of relative importance was $\mathrm{pH} \approx \mathrm{MLSS}>\mathrm{HRT}>$ influent COD.

3. Polyphenol oxidase and urease can serve as the indicating factors for reactor performance, whereas dehydrogenase and nitrate reductase are less susceptible towards varied influent COD and MLSS.

\section{References}

[1] Sun, C., Leiknes, T., Weitzenböck, J., Thorstensen, B. "Development of an integrated shipboard wastewater treatment system using biofilm-MBR", Separation and Purification Technology, 75(1), pp. 22-31, 2010. https://doi.org/10.1016/j.seppur.2010.07.005

[2] Xia, S., Guo, J., Wang, R. "Performance of a pilot-scale submerged membrane bioreactor (MBR) in treating bathing wastewater", Bioresource Technology, 99(15), pp. 6834-6843, 2008. https://doi.org/10.1016/j.biortech.2008.01.044

[3] Chen, Z., Wang, H., Ren, N., Chen, Z., Cui, M., Nie, S. "Performance and model of a novel membrane bioreactor to treat the low-strengthen complex wastewater", Bioresource Technology, 114, pp. 33-45, 2012.

https://doi.org/10.1016/j.biortech.2012.02.026

[4] Chang, J.-S., Chang, C.-Y., Chen, A.-C., Erdei, L., Vigneswaran, S. "Long-term operation of submerged membrane bioreactor for the treatment of high strength acrylonitrile-butadiene-styrene (ABS) wastewater: effect of hydraulic retention time", Desalination, 191(1-3), pp. 45-51, 2006.

https://doi.org/10.1016/j.desal.2005.07.020

[5] Wang, Z., Chu, J., Song, Y., Cui, Y., Zhang, H., Zhao, X., Li, Z., Yao, J. "Influence of operating conditions on the efficiency of domestic wastewater treatment in membrane bioreactors", Desalination, 245(1), pp. 73-81, 2009.

https://doi.org/10.1016/j.desal.2008.06.011

[6] Han, H., Zhang, Y., Cui, C., Zheng, S. "Effect of COD level and HRT on microbial community in a yeast-predominant activated sludge system", Bioresource Technology, 101(10), pp. 3463-3465, 2010. https://doi.org/10.1016/j.biortech.2009.12.121

[7] Fallah, N., Bonakdarpour, B., Nasernejad, B., Alavi Moghadam, M. R. "Long-term operation of submerged membrane bioreactor (MBR) for the treatment of synthetic wastewater containing styrene as volatile organic compound (VOC): Effect of hydraulic retention time (HRT)", Journal of Hazardous Materials, 178(1-3), pp. $718-724,2010$

https://doi.org/10.1016/j.jhazmat.2010.02.001

[8] Rodríguez, F. A., Reboleiro-Rivas, P., González-López, J., Hontoria, E., Poyatos, J. M. "Comparative study of the use of pure oxygen and air in the nitrification of a MBR system used for wastewater treatment", Bioresource Technology, 121, pp. 205-211, 2012. https://doi.org/10.1016/j.biortech.2012.06.053

\section{Acknowledgement}

This research was financially supported by the National Key R\&D Plan of China (2017YFC1404605), the Natural Science Foundation of China (Grant No. 51579049 and 51509044), the Fundamental Research Funds for the Central Universities (HEUCFG201820) and the High Tech Ship Program (17KJ-003).

[9] McNicholl, B. P., McGrath, J. W., Quinn, J. P. "Development and application of a resazurin-based biomass activity test for activated sludge plant management", Water Research, 41(1), pp. 127-133, 2007.

https://doi.org/10.1016/j.watres.2006.10.002

[10] Liu, Y., Tay, J.-H. "Strategy for minimization of excess sludge production from the activated sludge process", Biotechnology Advances, 19(2), pp. 97-107, 2001. https://doi.org/10.1016/S0734-9750(00)00066-5

[11] Saby, S., Djafer, M., Chen, G.-H. "Feasibility of using a chlorination step to reduce excess sludge in activated sludge process", Water Research, 36(3), pp. 656-666, 2002. https://doi.org/10.1016/S0043-1354(01)00259-7

[12] Meng, F., Yang, F. "Fouling mechanisms of deflocculated sludge, normal sludge, and bulking sludge in membrane bioreactor", Journal of Membrane Science, 305(1), pp. 48-56, 2007. https://doi.org/10.1016/j.memsci.2007.07.038

[13] Zuriaga-Agustí, E., Garrido-Mauri, G., Mendoza-Roca, J. A., BesPiá, A., Alonso-Molina, J. L. "Reduction of the sludge production in a sequencing batch reactor by addition of chlorine dioxide: Influence on the process performance", Chemical Engineering Journal, 209, pp. 318-324, 2012 https://doi.org/10.1016/j.cej.2012.08.004

[14] Tian, Y., Lu, Y., Li, Z. "Performance analysis of a combined system of membrane bioreactor and worm reactor: Wastewater treatment, sludge reduction and membrane fouling", Bioresource Technology, 121, pp. 176-182, 2012 https://doi.org/10.1016/j.biortech.2012.06.071

[15] Di Trapani, D., Capodici, M., Cosenza, A., Di Bella, G., Mannina, G., Torregrossa, M., Viviani, G. "Evaluation of biomass activity and wastewater characterization in a UCT-MBR pilot plant by means of respirometric techniques", Desalination, 269(1), pp. 190-197, 2011. https://doi.org/10.1016/j.desal.2010.10.061

[16] Eaton, A. D., Clesceri, L. S., Rice, E. W., Greenberg, A. E. (eds.), "Standard Methods for the Examination of Water and Wastewater", 21st ed., American Public Health Association/American Water Works Association/Water Environment Federation, Washington, D.C., USA, 2005. 
[17] Kumar, V. B. A., Mohan, T. C. K., Murugan, K. "Purification and kinetic characterization of polyphenol oxidase from Barbados cherry (Malpighia glabra L.)", Food Chemistry, 110(2), pp. 328333, 2008.

https://doi.org/10.1016/j.foodchem.2008.02.006

[18] Hoffmann, G., Teicher, K. "Ein kolorimetrisches Verfahren zur Bestimmung der Ureaseaktivität in Böden" (A colorimetric method for determining urease activity in soils), Zeitschrift für Pflanzenernährung, Düngung, Bodenkunde, 95(1), pp. 55-63, 1961. (in German) https://doi.org/10.1002/jpln.19610950107

[19] Serra-Wittling, C., Houot, S., Barriuso, E. "Soil enzymatic response to addition of municipal solid-waste compost", Biology and Fertility of Soils, 20(4), pp. 226-236, 1995. https://doi.org/10.1007/BF00336082

[20] Corzo, A., Niell, F. X. "Determination of nitrate reductase activity in Ulva rigida C. Agardh by the in situ method", Journal of Experimental Marine Biology and Ecology, 146(2), pp. 181-191, 1991. https://doi.org/10.1016/0022-0981(91)90024-Q

[21] Shi, Y., Zhao, X., Zhang, Y., Ren, N. "Back propagation neural network (BPNN) prediction model and control strategies of methanogen phase reactor treating traditional Chinese medicine wastewater (TCMW)", Journal of Biotechnology, 144(1), pp. 70-74, 2009. https://doi.org/10.1016/j.jbiotec.2009.08.014

[22] Zhang, S., Yang, F., Liu, Y., Zhang, X., Yamada, Y., Furukawa, K. "Performance of a metallic membrane bioreactor treating simulated distillery wastewater at temperatures of 30 to $45^{\circ} \mathrm{C}$, Desalination, 194(1), pp. 146-155, 2006. https://doi.org/10.1016/j.desal.2005.10.029

[23] Chen, Z., Ren, N., Wang, A., Zhang, Z.-P., Shi, Y. "A novel application of TPAD-MBR system to the pilot treatment of chemical synthesis-based pharmaceutical wastewater", Water Research, 42(13), pp. 3385-3392, 2008.

https://doi.org/10.1016/j.watres.2008.04.020

[24] Al-Amri, A., Salim, M. R., Aris, A. "The effect of different temperatures and fluxes on the performance of membrane bioreactor treating synthetic-municipal wastewater", Desalination, 259(1-3), pp. 111-119, 2010.

https://doi.org/10.1016/j.desal.2010.04.023

[25] Huang, Z., Ong, S. L., Ng, H. Y. "Submerged anaerobic membrane bioreactor for low-strength wastewater treatment: Effect of HRT and SRT on treatment performance and membrane fouling", Water Research, 45(2), pp. 705-713, 2011. https://doi.org/10.1016/j.watres.2010.08.035

[26] Martinez-Sosa, D., Helmreich, B., Horn, H. "Anaerobic submerged membrane bioreactor (AnSMBR) treating low-strength wastewater under psychrophilic temperature conditions", Process Biochemistry, 47(5), pp. 792-798, 2012. https://doi.org/10.1016/j.procbio.2012.02.011
[27] Hu, D., Li, X., Chen, Z., Cui, Y., Gu, F., Jia, F., Xiao, T., Su, H., Xu, J., Wang, H., Wu, P., Zhang, Y. "Performance and extracellular polymers substance analysis of a pilot scale anaerobic membrane bioreactor for treating tetrahydrofuran pharmaceutical wastewater at different HRTs", Journal of Hazardous Materials, 342, pp. 383-391, 2018.

https://doi.org/10.1016/j.jhazmat.2017.08.028

[28] Kawasaki, K., Maruoka, S., Katagami, R., Bhatta, C. P., Omori, D., Matsuda, A. "Effect of initial MLSS on operation of submerged membrane activated sludge process", Desalination, 281, pp. 334-339, 2011.

https://doi.org/10.1016/j.desal.2011.08.013

[29] Yue, X., Yu, G., Liu, Z., Tang, J., Liu, J. "Fast start-up of the CANON process with a SABF and the effects of $\mathrm{pH}$ and temperature on nitrogen removal and microbial activity", Bioresource Technology, 254, pp. 157-165, 2018. https://doi.org/10.1016/j.biortech.2018.01.019

[30] Cao, X., Fu, K., Qian, D., Zhu, Z., Meng, X. "Effect of C/N ratio on nitrite accumulation in dentrifying process with methanol as carbon source", CIESC Journal, 61(11), pp. 2939-2943, 2010. [online] Available at: http://www.hgxb.com.cn [Accessed: 30 October 2018]

[31] LaPara, T. M., Nakatsu, C. H., Pantea, L. M., Alleman, J. E. "Aerobic Biological Treatment of a Pharmaceutical Wastewater: Effect of Temperature on COD Removal and Bacterial Community Development", Water Research, 35(18), pp. 4417-4425, 2001. https://doi.org/10.1016/S0043-1354(01)00178-6

[32] Cui, F., Park, S., Kim, M. "Characteristics of aerobic granulation at mesophilic temperatures in wastewater treatment", Bioresource Technology, 151, pp. 78-84, 2014. https://doi.org/10.1016/j.biortech.2013.10.025

[33] Chen, Z., He, Z., Hu, D., Cui, Y., Ran, C., Ge, H., Zhang, S., Shi, Y., Yang, M., Wang, A., Chen, Z, Ren, N. "Effect of temperature on treating chemical synthesis-based pharmaceutical wastewater containing 7-ACA by a novel multi-stage loop membrane bioreactor", Journal of Chemical Technology and Biotechnology, 90(6), pp. 1002-1012, 2015.

https://doi.org/10.1002/jctb.4402

[34] Edwards, W., Bownes, R., Leukes, W. D., Jacobs, E. P., Sanderson, R., Rose, P. D., Burton, S. G. "A capillary membrane bioreactor using immobilized polyphenol oxidase for the removal of phenols from industrial effluents", Enzyme and Microbial Technology, 24(3-4), pp. 209-217, 1999. https://doi.org/10.1016/S0141-0229(98)00110-0

[35] Mayer, A. M. "Polyphenol oxidases in plants and fungi: Going places? A review", Phytochemistry, 67(21), pp. 2318-2331, 2006. https://doi.org/10.1016/j.phytochem.2006.08.006

[36] Gawlik-Dziki, U., Szymanowska, U., Baraniak, B. "Characterization of polyphenol oxidase from broccoli (Brassica oleracea var. botrytis italica) florets", Food Chemistry, 105(3), pp. 1047-1053, 2007. https://doi.org/10.1016/j.foodchem.2007.05.012 
[37] Valero, E., Varón, R., García-Carmona, F. "Characterization of Polyphenol Oxidase from Airen Grapes", Journal of Food Science, 53(5), pp. 1482-1485, 1988.

https://doi.org/10.1111/j.1365-2621.1988.tb09304.x

[38] Kız1lkaya, R., Bayrakl1, B. "Effects of N-enriched sewage sludge on soil enzyme activities", Applied Soil Ecology, 30(3), pp. 192 202, 2005.

https://doi.org/10.1016/j.apsoil.2005.02.009

[39] Follmer, C. "Insights into the role and structure of plant ureases", Phytochemistry, 69(1), pp. 18-28, 2008. https://doi.org/10.1016/j.phytochem.2007.06.034

[40] Pandey, P. C., Mishra, A. P. "Novel potentiometric sensing of creatinine", Sensors and Actuators B: Chemical, 99(2), pp. 230-235, 2004. https://doi.org/10.1016/j.snb.2003.11.016

[41] Guo, Q., Zhao, L. "Study on multi-stage loop and aerating technology in treatment of industrial wastewater", Environmental Science Survey, 26, pp. 44-47, 2007.

https://doi.org/10.13623/j.cnki.hkdk.2007.02.016

[42] Förstner, U. "Water Pollution: Wastewater", In: Weissbach, A., Boeddecker, H. (eds.) Integrated Pollution Control, SpringerVerlag, Berlin Heidelberg, 1998, pp. 197-328. https://doi.org/10.1007/978-3-642-80311-6_6

[43] Fang, J., Ju, O., Qiu, J., Chen, K. "Regularity for Change of Urease and Catalase in Wastewater Treatment with Activated Sludge Process", In: 2010 4th International Conference on Bioinformatics and Biomedical Engineering, Chengdu, China, 2010, pp. 1-5. https://doi.org/10.1109/ICBBE.2010.5515691
[44] Bell, L. C., Richardson, D. J., Ferguson, S. J. "Periplasmic and membrane-bound respiratory nitrate reductases in Thiosphaera pantotropha", FEBS Letters, 265(1-2), pp. 85-87, 2018. https://doi.org/10.1016/0014-5793(90)80889-Q

[45] Lazcano, C., Gómez-Brandón, M., Revilla, P., Domínguez, J. "Short-term effects of organic and inorganic fertilizers on soil microbial community structure and function: A field study with sweet corn", Biology and Fertility of Soils, 49(6), pp. 723-733, 2013.

https://doi.org/10.1007/s00374-012-0761-7

[46] Chen, Z., Hu, D., Ren, N., Zhang, Z.-P. "Simultaneous removal of organic substances and nitrogen in pilot-scale submerged membrane bioreactors treating digested traditional Chinese medicine wastewater", International Biodeterioration \& Biodegradation, 62(3), pp. 250-256, 2008.

https://doi.org/10.1016/j.ibiod.2008.01.010

[47] Chen, Z., Wang, H., Chen, Z., Ren, N., Wang, A., Shi, Y., Li, X. "Performance and model of a full-scale up-flow anaerobic sludge blanket (UASB) to treat the pharmaceutical wastewater containing 6-APA and amoxicillin", Journal of Hazardous Materials, 185(2), pp. 905-913, 2011.

https://doi.org/10.1016/j.jhazmat.2010.09.106 